\title{
Coarse and Fine Particulate Matter Components of Wildland Fire Smoke at Devils Postpile National Monument, California, USA
}

\author{
Donald Schweizer $^{1,2^{*}}$, Ricardo Cisneros ${ }^{2}$, Monica Buhler ${ }^{3}$ \\ ${ }^{1}$ USDA Forest Service, Bishop, CA 93514, USA \\ ${ }^{2}$ University of California, Merced, CA 95343, USA \\ ${ }^{3}$ Devils Postpile National Monument, Mammoth Lakes, CA 93546, USA
}

\begin{abstract}
Fine $\left(\mathrm{PM}_{2.5}\right)$ and coarse $\left(\mathrm{PM}_{10}\right)$ particulate matter were monitored during the summer and fall of 2018 at Devils Postpile National Monument, California, USA. This remote site, located in the Sierra Nevada, was downwind of a number of wildland fires that were burning in California. The coarse $\left(\mathrm{PM}_{2.5-10}\right)$ and the fine $\left(\mathrm{PM}_{2.5}\right)$ fractions of the PM in the wildland fire smoke showed median $\mathrm{PM}_{2.5-10} / \mathrm{PM}_{2.5}$ ratios of .47 and 1.37 during periods with and without smoke, respectively. The concentrations at ground level were significantly $(\mathrm{p}<0.001)$ higher during the periods with smoke for both the $\mathrm{PM}_{2.5-10}$ $\left(10.3 \mu \mathrm{g} \mathrm{m}^{-3}\right)$ and the $\mathrm{PM}_{2.5}\left(35.3 \mu \mathrm{g} \mathrm{m}^{-3}\right)$, although the $\mathrm{PM}_{2.5}$ contributed most of the increase. These concentrations suggest that the fire size and intensity along with the distance and transport of smoke determine the exposure risk to humans. Current exposure estimates obtained via modeling and emission estimates may misrepresent ground-level concentrations due to a lack of understanding of the aerosol distribution in an aging wildland fire smoke plume.
\end{abstract}

Keywords: $\mathrm{PM}_{2.5} ; \mathrm{PM}_{10}$; Wilderness air quality; Emission characterization.

\section{INTRODUCTION}

Wildland fire is increasing in size and intensity in the California Sierra Nevada from a history of fire suppression and climate change (Miller et al., 2009; Miller and Safford, 2017; Collins et al., 2019). Increased wildfire has brought increased awareness and interest in understanding public tradeoffs of different fire management strategies when assessing public health impacts (Black et al., 2017; Cascio, 2018).

Particulate matter (PM) is understood to be a significant pollutant in wildland fire emissions (Fowler, 2003) and is often used in exposure assessments of wildland fire smoke (Navarro et al., 2018; Sharma and Balasubramanian, 2018). Review studies have largely relied on combining studies of fine particulate matter less than 2.5 microns in aerodynamic diameter $\left(\mathrm{PM}_{2.5}\right)$, total particulate matter less than 10 microns in aerodynamic diameter $\left(\mathrm{PM}_{10}\right)$, and the coarse fraction of PM $\left(\mathrm{PM}_{2.5-10}\right)$ to obtain conclusions (Reid et al., 2016). Wildland fire $\mathrm{PM}_{2.5}$ and $\mathrm{PM}_{2.5-10}$ have both been shown to contribute similarly to lung damage in mice but the understanding of toxicity in dosage for PM of different size

\footnotetext{
* Corresponding author.

Tel.: 1-960-920-5790

E-mail address: dschweizer@ucmerced.edu
}

is largely an assumption with intratracheal instillation route masking $\mathrm{PM}_{2.5-10}$ toxicity of actual $\mathrm{PM}$ dosage in the lungs by altering the delivery during inhalation (Wegesser et al., 2009). Air quality impacts from all wildland fire are similarly categorized whether they burn only timber or have a large component of emissions from structures or other toxins from manufactured items or industry (Landis et al., 2018; Wentworth et al., 2018).

While little study has been done to understand the physical and chemical characteristics and toxicity of PM, virtually none has been done to compare differences in smoke from wilderness fires versus wildland fires burning homes. Ignoring toxicity of various emission sources and grouping all wildland fire smoke into one category limits the veracity of current public health and exposure assessments.

$\mathrm{PM}$ is a complex mixture of chemical species from anthropogenic and natural emission sources and secondary pollutants which form in the atmosphere. $\mathrm{PM}_{2.5-10}$ has been found to be dominated by crustal trace elements (e.g., Al, As, $\mathrm{Cd}, \mathrm{K}$, and $\mathrm{V}$ ) except immediately adjacent to roads, where vehicle-generated emissions can dominate over these naturally occurring elements (Hueglin et al., 2005). Other trace elements of $\mathrm{PM}_{2.5}$ (e.g., $\mathrm{Ba}, \mathrm{Ca}, \mathrm{Ce}, \mathrm{Cu}, \mathrm{Fe}, \mathrm{La}$, $\mathrm{Mo}, \mathrm{Mn}, \mathrm{Pb}, \mathrm{Sb}$, and $\mathrm{Rh}$ ) are mainly from anthropogenic processes and gradually reduce from urban to rural areas (Hueglin et al., 2005). Secondary aerosol formation (sulfate and nitrate), while typically associated with the $\mathrm{PM}_{2.5}$ component of $\mathrm{PM}$, is variable and can have a significant 
fraction in $\mathrm{PM}_{2.5-10}$ (Diapouli et al., 2017).

Understanding of accuracy and precision and the limits of agreement of varying PM monitoring methods to obtain data is integral to understanding comparability of conclusions (Schweizer et al., 2016). Review studies assessing smoke exposure often rely on PM monitoring data from varying methods without acknowledging this weakness or including analyses in the robustness of using specific measurements comparatively.

Emissions estimates suggest nearly $90 \%$ of wildfire emissions are $\mathrm{PM}_{2.5}$ (Vicente et al., 2013; Huang et al., 2014). Meteorological conditions have a role in PM size distribution (Kozákovác et al., 2018; Thuy et al., 2018). Estimates of emissions are done in both lab and field settings but are often limited in time and number of samples. Chamber studies show high variability in emissions factors depending on many characteristics (Cereceda-Balic et al., 2017) while prescribed and wildland fire estimates are limited by monitor siting (Evtyugina et al., 2013; Reisen et al., 2018). The aging of wildland fire smoke plumes has long been understood to alter PM size distribution through coagulation and removal causing impacts of smoke to be mitigated more rapidly than predicted (Radke et al., 1995). Ground-level monitoring of $\mathrm{PM}_{2.5}$ and $\mathrm{PM}_{10}$ used to compare physical distribution of PM particularly in remote locations in fire-prone areas has been little documented.

The fire-prone landscape of the California Sierra Nevada has large areas of federal and state protected lands including federally designated wilderness areas. Devils Postpile National Monument (DEPO) in the Sierra Nevada of California has a history of air pollutant monitoring and assessments where wildfire has been shown to elevate an otherwise extremely low background concentration of $\mathrm{PM}_{2.5}$ (Bytnerowicz et al., 2013; Burley et al., 2016). During 2018, smoke transported from local wildland fires and wildfires across California impacted the site. The objective of this study was to assess current background physical properties of PM when wildland fire smoke was not present and when smoke impacted PM during 2018 at DEPO. Sampling at DEPO provides empirical ground-based data of particle size dynamics in a fire-prone area with little anthropogenic source contribution more consistent with wilderness than rural or urban areas because of its location in wilderness far from anthropogenic sources of emissions. The $\mathrm{PM}_{2.5}$ component was the primary constituent of $\mathrm{PM}_{10}$ when wildland fire smoke was present. During smoke-free periods, the ratio of $\mathrm{PM}_{2.5} / \mathrm{PM}_{2.5-10}$ varied from over 4 times to as little as 0.37. In the presence of smoke, $\mathrm{PM}_{2.5} / \mathrm{PM}_{2.5-10}$ ratios were typical of background levels with no smoke. The high variability suggests the $\mathrm{PM}_{2.5} / \mathrm{PM}_{2.5-10}$ components at ground level in the field are much less static and consistent than currently expected when considering fire emissions alone.

\section{METHODS}

\section{Site Description}

DEPO is located along a section of the Middle Fork of the San Joaquin River at about 2,200 to 2,500 $\mathrm{m}$ in elevation. It is 322 ha in size, 302 ha of which is in the Ansel Adams Wilderness surrounded by the Inyo National Forest. Monitoring was conducted on the north end of DEPO approximately $7 \mathrm{~km}$ from the town of Mammoth Lakes (Fig. 1). DEPO is unique in that it is hydrologically located on the western slope of the Sierra Nevada near the lowest pass on the Sierra Divide and is in very close proximity to the eastern slope of the Sierra Nevada. Previous studies show that air quality in DEPO is impacted by the transport of pollutants from the Central Valley and farther west along with wildland fire smoke from the adjacent and local fire-prone landscape, particularly from the west (Bytnerowicz et al., 2013; Burley et al., 2016; Bytnerowicz et al., 2016, 2019).

\section{Particulate Monitor Settings and Quality Assurance}

Two Met One Instruments, Inc. Environmental Beta Attenuation Monitors (E-BAMs) were co-located to collect hourly averages of fine particulate matter less than 2.5 microns in diameter $\left(\mathrm{PM}_{2.5}\right)$ and particulate matter less than 10 microns in diameter $\left(\mathrm{PM}_{10}\right)$ at Devils Postpile National Monument in California (Fig. 1) from June 13, 2018, to October 15, 2018. E-BAMs were installed $2 \mathrm{~m}$ distance apart with inlets within $0.5 \mathrm{~m}$ in vertical height. Internal settings were consistent between each E-BAM (e.g., date and time, tape advance, and internal relative humidity set points). E-BAMs were calibrated and audited for integrity of flow (leak check), temperature, and flow rate at a minimum of once every 2 weeks (Met One Instruments, Inc., 2008). Data validity required flow to be $16.7 \pm 0.8 \mathrm{~L} \mathrm{~min}^{-1}$, temperature $\pm 2.0^{\circ} \mathrm{C}$, and atmospheric pressure $\pm 2 \%$, and leak check $<1.5 \mathrm{~L} \mathrm{~min}^{-1}$.

\section{Data Compilation, Handling, and Quality Control}

E-BAM hourly values were used to calculate daily 24-hour averages so agreement could be aligned to more robust monitors used in compliance monitoring for particulate monitoring and not limited to simple association with correlation subject to misinterpretation on accuracy and precision (Schweizer et al., 2016). Negative E-BAM hourly values were set as 0 and a minimum of 18 valid hourly values were required to get a valid daily mean concentration. All calculations were done using the $\mathrm{R}$ software environment (Adler and Kelly, 2018; R Core Team, 2018).

Presence of smoke from wildland fire used field observations (e.g., personal observations, photo documentation, field notes) at the site during the E-BAM deployment. Satellite imagery along with fire and smoke reports were included in the determination of smoke impacts from wildland fire impacting the monitors for fire size, location, and distance from the site.

The E-BAM data included hourly averages of the meteorological variables including wind speed and direction, relative humidity, and ambient temperature. Meteorological conditions were used to compare smoke and times without the presence of wildland fire smoke and assess likelihood of error from environmental factors especially relative humidity (Schweizer et al., 2016). 

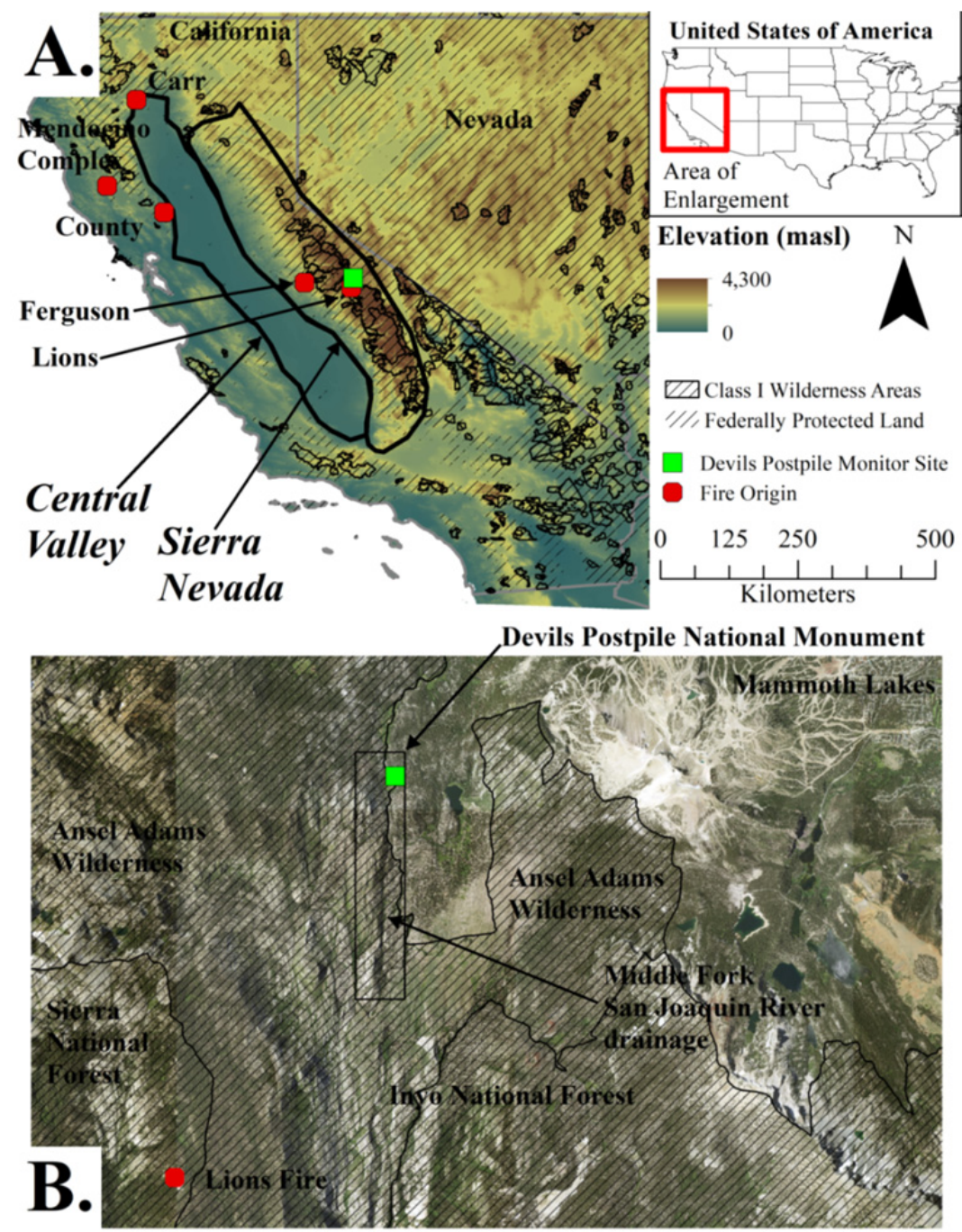

Fig. 1. A. Monitoring and major fire overview, B. Devils Postpile and surrounding area map.

\section{RESULTS}

\section{Site Meteorological Conditions}

The DEPO monitor site is in the canyon of the Middle Fork of the San Joaquin River. The San Joaquin River flows generally north to south at the site with the steep canyon walls oriented similarly. The site was characterized by consistent ground-level winds. The wind pattern consisted of winds that flowed from the northeast from midnight until the site experienced a calm period around 08:00, followed by a change to winds that came from the southeast until another calm period near 23:00 or 00:00 indicated the shift from predominantly down-canyon to upcanyon winds and the cycle repeated. Median wind speed $\left(0.6 \mathrm{~m} \mathrm{~s}^{-1}\right)$ was similar for both smoke and non-smoke times with the maximum wind speed of $5.3 \mathrm{~m} \mathrm{~s}^{-1}$ during the time without smoke. When smoke was present, wind speed had a $2.4 \mathrm{~m} \mathrm{~s}^{-1}$ maximum.

Maximum $\left(34.6^{\circ} \mathrm{C}\right)$ and minimum $\left(-3.7^{\circ} \mathrm{C}\right)$ temperature occurred when wildland fire smoke was not present. Because of seasonal normal, as expected, median and mean temperatures were higher when smoke was present (4.4 and $3.9^{\circ} \mathrm{C}$ respectively).

Relative humidity at the site varied from $\sim 5 \%$ to $90 \%$ with both smoke and non-smoke times nearly identical. $\mathrm{RH}$ was highest overnight, lowering in the morning to lows around 14:00.

\section{Wildland Fire Smoke Impacts}

Wildland fire smoke impacted the monitoring site during June 23-July 7, 2018; July 7-August 13, 2018; August 16August 18, 2018; and September 1-2, 2018, periods. During these periods, smoke was present from a single hour to the entire day. A number of large fires produced smoke that impacted much of California including the monitor at DEPO. Large regional fires contributed to smoke at the site but smoke was primarily from the nearest fires. Large regional fires occurring at the same time include the County Fire (start: June 30, 2018; 37,000 ha; $\sim 300 \mathrm{~km}$ west-northwest), Carr Fire (start: July 23, 2018; 93,000 ha; $\sim 450 \mathrm{~km}$ northwest), Mendocino Complex (start: July 27, 2018; 186,000 ha; $400 \mathrm{~km}$ northwest), and the Donnell Fire (start: August 1, 2018; 15,000 ha; 110 km northwest).

The Lions Fire was ignited by lightning on or around 
June 1, 2018, in the John Muir Wilderness. Fire management strategy of this fire was largely indirect "confine and contain" because of the remoteness, high potential for resource benefit and fuel reduction, and the low potential of impact to life and property. Therefore, the Lions Fire primarily burned up to natural barriers and containment lines strategically placed at a distance from the fire. The Lions Fire had a maximum 1-day growth of 456 ha on August 10, 2018, with 6 additional days of fire growth $>200$ ha and 15 days where fire growth was 100-200 ha. The fire burned less than 4 ha until June 23, 2018, when the fire spread to an estimated 400 ha. Until that time, no smoke was detected at the DEPO site. The Lions Fire largely stopped spreading at approximately 1,600 ha by July 2, 2018, with smoke continuing to be present at the site until July 7, 2018, while fuels within the perimeter continued to burn. The Lions Fire began contributing to smoke at the site as the perimeter began to grow again starting about July 30 adding to smoke from the Ferguson Fire. The Lions Fire continued to move west and away from the site and contributed to smoke at the site until September 2, 2018.

The Ferguson Fire was a full-suppression fire that started July 13, 2018. Daily growth of the fire from July 15 to August 6, 2018, varied from 1,000 to 3,000 ha. The Ferguson Fire contributed smoke to DEPO from July 24 to mid-August. Other fires (e.g., Lions Fire) contributed to smoke at DEPO. The Ferguson Fire was the primary contributor to the DEPO site from July 24 to the end of July. Even though the Ferguson Fire was farther from the site than other fires that impacted DEPO, the high-intensity burn of this fire increased injection height of the emissions to upper air winds where predominant transport is to DEPO.

Smoke input from several other fires coincided with the smoke from the Lions Fire (5,400 ha), which was approximately $6 \mathrm{~km}$ south-southwest of the monitors and the Ferguson Fire $(39,000 \mathrm{ha})$ approximately $80 \mathrm{~km}$ west. Dominant wind patterns largely from the west, including the fire-prone western slopes of the Sierra Nevada, typically transport smoke from these locations to DEPO, while smaller fires often have impacts enhanced locally by drainage transport and local ground-level wind direction. The Ferguson Fire being over 7 times larger and generally burning larger areas per day had similar impacts on the DEPO site (Ferguson/Lions Fires median: $\mathrm{PM}_{2.5}$ : 39.8/45.7 $\mu \mathrm{g} \mathrm{m}^{-3}$; $\mathrm{PM}_{10}: 66.0 / 80.4 \mu \mathrm{g} \mathrm{m}^{-3}$ ) as the Lions Fire. The Lions Fire smoke impacts were more localized than the Ferguson Fire, but nearness and local transport in the surrounding drainages made smoke contributions similar at this location.

\section{Particulate Matter Contributions}

Daily mean concentrations of PM were calculated from June 13, 2018, to October 15, 2018 ( $\mathrm{n}=123$ days), with 84 days of valid data for both $\mathrm{PM}_{10}$ and $\mathrm{PM}_{2.5}$. For all days with available data, the maximum daily mean $\mathrm{PM}_{2.5}$ concentration was $200.8 \mu \mathrm{g} \mathrm{m}^{-3}$ and the minimum $1.7 \mu \mathrm{g} \mathrm{m}^{-3}$. $\mathrm{PM}_{10}$ concentrations ranged from 5.2 to $229.0 \mu \mathrm{g} \mathrm{m}^{-3}$.

Over the 123 days, there were 84 days where there was data for both $\mathrm{PM}_{10}$ and $\mathrm{PM}_{2.5}$. A Mann-Whitney $U$ test showed a significant difference $(p<0.001)$ between both $\mathrm{PM}_{2.5}$ and $\mathrm{PM}_{2.5-10}$ on smoke free and smoke impacted days. Mann-Whitney $U$ test estimated $\mathrm{PM}_{2.5}$ increased $35.3 \mu \mathrm{g} \mathrm{m}^{-3}$ (95\% CI: 26.7-48.0 $\mu \mathrm{g} \mathrm{m}^{-3}$ ) and $\mathrm{PM}_{2.5-10}$ increased $10.33 \mu \mathrm{g} \mathrm{m}^{-3}$ (95\% CI: 7.6-14.3 $\mu \mathrm{g} \mathrm{m}^{-3}$ ) with smoke.

$\mathrm{PM}_{2.5-10}$ was calculated for 33 days that were impacted by wildland fire smoke and 51 days with no wildland fire smoke. Mean concentrations were similar between $\mathrm{PM}_{2.5}$ $\left(9.1 \mu \mathrm{g} \mathrm{m}^{-3}\right)$ and $\mathrm{PM}_{2.5-10}\left(10.9 \mu \mathrm{g} \mathrm{m}^{-3}\right)$ concentrations when smoke was not present, while mean $\mathrm{PM}_{2.5}$ was over 2.5 times greater $\left(63.8 \mu \mathrm{g} \mathrm{m}^{-3}\right)$ than the concentration of $\mathrm{PM}_{2.5-10}\left(24.1 \mu \mathrm{g} \mathrm{m}^{-3}\right)$ when wildland fire smoke was present (Table 1).

$\mathrm{PM}_{2.5-10}$ increased in the presence of wildland smoke but the increase and distribution was primarily in the concentrations of $\mathrm{PM}_{2.5}$ (Fig. 2). Smoke impacted $\mathrm{PM}_{2.5-10}$ was above the maximum no-smoke $\mathrm{PM}_{2.5-10}$ concentration for 4 days $\left(37.5,48.6,58.0\right.$, and $60.9 \mu \mathrm{g} \mathrm{m}^{-3}$ ) while smoke impacted $\mathrm{PM}_{2.5}$ was above the maximum no-smoke $\mathrm{PM}_{2.5}$ concentration for 21 of the 33 days. The $\mathrm{PM}_{2.5}$ component consistently showed when smoke was present at the site, while the $\mathrm{PM}_{2.5-10}$ correlated weaker to the presence of smoke.

The mean percentage contribution of $\mathrm{PM}_{2.5}$ to $\mathrm{PM}_{10}$ when smoke was present was $66 \%$ whereas contributions to days without wildland fire smoke was $44 \%$. Days without smoke frequently had a larger contribution of $\mathrm{PM}_{2.5-10}$ than $\mathrm{PM}_{2.5}$, but when daily mean concentrations of $\mathrm{PM}_{10}$ in the presence of smoke reached $100 \mu \mathrm{g} \mathrm{m}^{-3}$, the primary component was $\mathrm{PM}_{2.5}$ (Fig. 3).

\section{DISCUSSION}

Background concentrations of PM when wildland fire smoke is not present are often low and evenly distributed between $\mathrm{PM}_{2.5}$ and $\mathrm{PM}_{2.5-10}$. When smoke from wildland

Table 1. Summary statistics for daily fine $\left(\mathrm{PM}_{2.5}\right)$ and coarse $\left(\mathrm{PM}_{2.5-10}\right)$ particulate matter concentrations at Devils Postpile National Monument in 2018 with and without wildland fire smoke.

\begin{tabular}{lllll}
\hline & \multicolumn{2}{r}{ 51 No Smoke Days $\left(\mu \mathrm{g} \mathrm{m}^{-3}\right)$} & & \multicolumn{2}{c}{33 Smoke Impacted Days $\left(\mu \mathrm{g} \mathrm{m} \mathrm{m}^{-3}\right)$} \\
\cline { 2 - 3 } \cline { 5 - 5 } & $\mathrm{PM}_{2.5}$ & $\mathrm{PM}_{2.5-10}$ & & $\mathrm{PM}_{2.5}$ \\
\hline Median & 6.8 & 10.0 & 48.4 & 20.0 \\
Mean & 9.1 & 10.9 & 63.8 & 24.1 \\
Standard Deviation & 6.1 & 4.5 & 51.4 & 12.6 \\
Maximum & 36.7 & 33.6 & 200.8 & 60.9 \\
Minimum & 1.7 & 4.7 & 12.9 & 6.1 \\
\hline
\end{tabular}




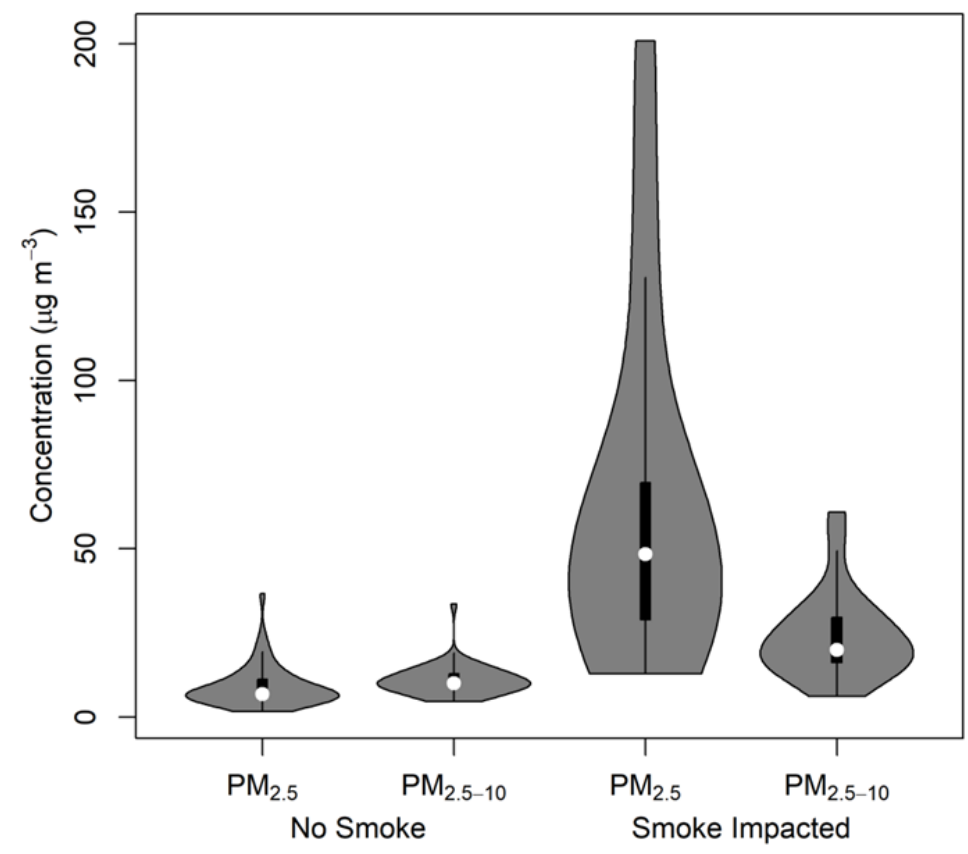

Fig. 2. Boxplot with kernel density plots of daily $\mathrm{PM}_{2.5}$ and $\mathrm{PM}_{2.5-10}$ in the presence and absence of wildland fire smoke at Devils Postpile National Monument in 2018.

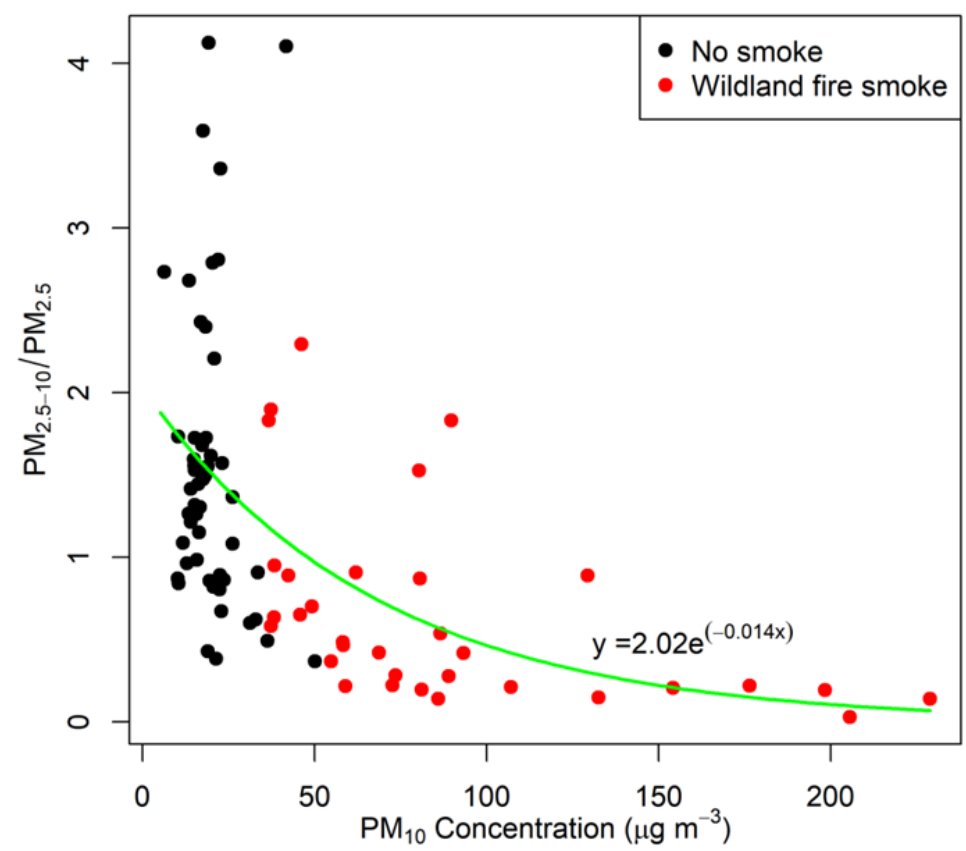

Fig. 3. The ratio of daily mean concentrations of the coarse particulate $\left(\mathrm{PM}_{2.5-10}\right)$ component to fine particulate $\left(\mathrm{PM}_{2.5}\right)$ component compared to coarse particulate $\left(\mathrm{PM}_{10}\right)$ daily mean with and without wildland fire smoke.

fire was present, the $\mathrm{PM}_{2.5}$ component was approximately two thirds of all $\mathrm{PM}_{10}$. The component ratio of $\mathrm{PM}_{2.5-10}$ to $\mathrm{PM}_{2.5}$ was typically comprised more of $\mathrm{PM}_{2.5}$ (mean: 1.54, SD: 0.91, max: 4.1, min: 3.7) on days with no smoke, while primarily (only 3 days 1 or greater) in the $\mathrm{PM}_{2.5-10}$ component (mean: 0.66, SD: 0.59, max.: 2.3, min.: 0.03) when smoke was present (Fig. 4). The $\mathrm{PM}_{2.5-10}$ did increase when smoke from wildland fire was present but mean change was almost 4 times larger for $\mathrm{PM}_{2.5}$.
Smoke from the Lions and Ferguson Fires were at times mixed. Smoke almost exclusively from the Ferguson Fire was limited to 8 days with only 5 having both $\mathrm{PM}_{10}$ and $\mathrm{PM}_{2.5}$ measurements. Because of the overlap of smoke contributing to the site and the limited number of days there was not a statistically significant difference in fine and coarse particulate components. Smoke from the nearer Lions Fire was attributed to the highest $\mathrm{PM}_{2.5-10}$ concentration days (Lions: $60.9 \mu \mathrm{g} \mathrm{m}^{-3}$; Ferguson: $30.1 \mu \mathrm{g} \mathrm{m}^{-3}$ ) and the 


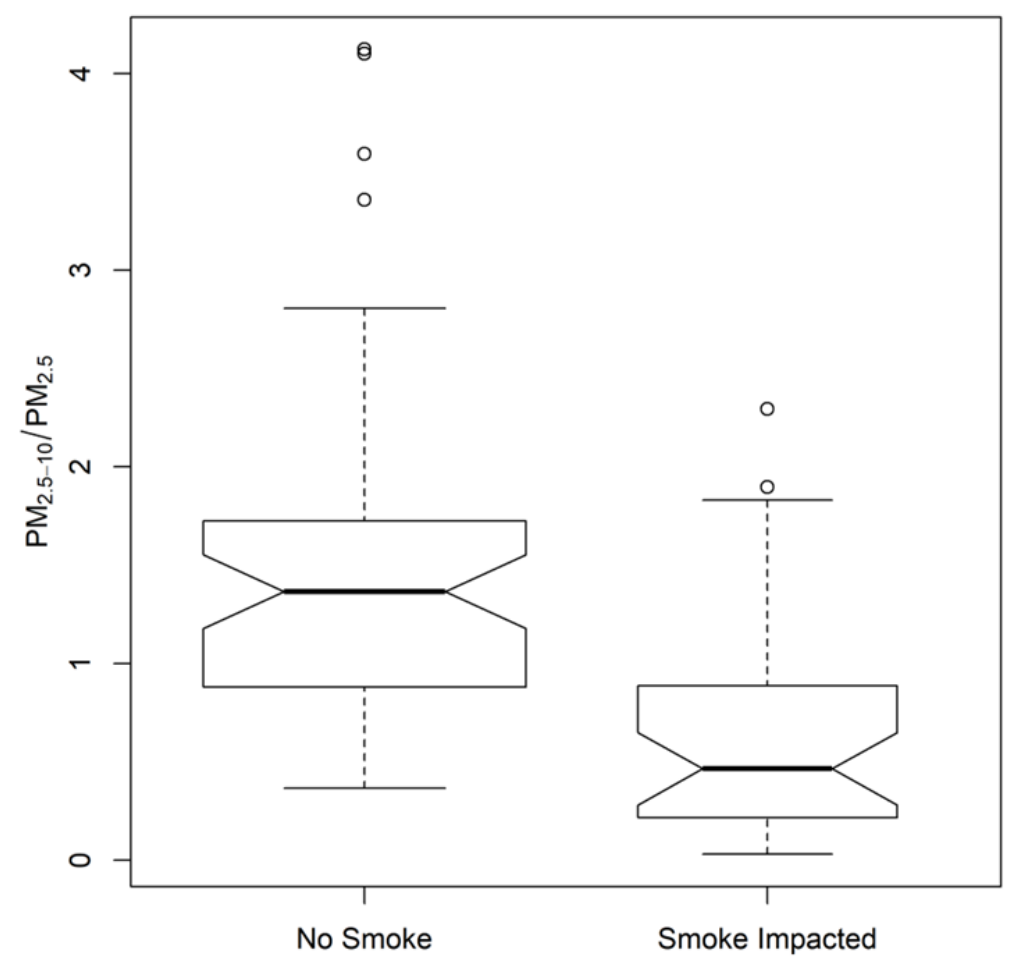

Fig. 4. Ratio of coarse particulate component $\left(\mathrm{PM}_{2.5-10}\right)$ and fine particulate matter component ( $\left.\mathrm{PM}_{2.5}\right)$ during days with no wildland fire smoke and smoke impacted days.

highest component ratio of $\mathrm{PM}_{2.5-10}$ to $\mathrm{PM}_{2.5}$ (Lions: 2.3; Ferguson: 1.0).

The complexity of smoke's physical and chemical properties is not unknown (Statheropoulos and Karma, 2007) with emission estimates also being dependent on vegetation and combustion efficiency (Hosseini et al., 2013). Limitations in understanding from users, and fire and weather models themselves can negatively impact the quality of models used for smoke emissions and dispersal (Coen, 2018). PM data is for one location during a single fire season and not a comprehensive analysis (including ultrafine particles and chemical speciation) with multiple monitors over many years. However, ground-level PM at DEPO shows a large variation from more static estimates and assumptions of wildland fire emissions. This area of understanding in smoke and human health exposure appears to be subject to error that has not been rigorously assessed and needs further comprehensive understanding of both emissions and plume dynamics.

Current health analysis depends on a static relation of PM to assess impacts from smoke. While emissions of $\mathrm{PM}_{2.5}$ from wildland fire in California forests have been estimated to be around $90 \%$ of the $\mathrm{PM}_{10}$ emitted (Stephens et al., 2007) and to range between $\sim 60$ and $75 \%$ for wildfire globally (Huang et al., 2014), DEPO monitoring showed ground-level concentrations ranging from 30 to $97 \%$ in the $\mathrm{PM}_{2.5}$ component in this remote forested environment.

\section{CONCLUSIONS}

The PM monitoring at DEPO demonstrates a limitation in general modeling assumptions for the distribution of PM in wildland fire smoke and the resultant ground-level concentrations. Further field-measured validation studies are needed to determine the physical distribution of PM in varying meteorological and transport scenarios and to evaluate the efficacy of using emissions to estimate the health impacts from smoke. Ground-level $\mathrm{PM}_{2.5}$ and $\mathrm{PM}_{2.5-10}$ in the wildland smoke at DEPO varied more than expected based on the emissions estimates, with transported smoke further increasing the concentration of $\mathrm{PM}_{2.5}$.

\section{ACKNOWLEDGEMENTS AND DISCLAIMERS}

The authors would like to thank the U.S. Forest Service Pacific Southwest Region Air Program for providing the monitoring equipment, the National Park Service at Devils Postpile National Monument for providing equipment power and siting, and the Student Conservation Association summer interns for their help in site maintenance. Reference to any companies or specific commercial products does not constitute an endorsement by the authors.

\section{REFERENCES}

Adler, D. and Kelly, S.T. (2018). vioplot: violin plot. R package version 0.3.0. https://cran.r-project.org/web/pac kages/vioplot/index.html

Black, C., Tesfaigzi, Y., Bassein, J.A. and Miller, L.A. (2017). Wildfire smoke exposure and human health: Significant gaps in research for a growing public health issue. Environ. Toxicol. Pharmacol. 55: 186-195. 
Burley, J.D., Bytnerowicz, A., Buhler, M., Zielinska, B., Schweizer, D., Cisneros, R., Schilling, S., Varela, J.C., McDaniel, M., Horn, M. and Dulen, D. (2016). Air quality at devils Postpile National Monument, Sierra Nevada Mountains, California, USA. Aerosol Air Qual. Res. 16: 2315-2332.

Bytnerowicz, A., Burley, J.D., Cisneros, R., Preisler, H.K., Schilling, S., Schweizer, D., Ray, J., Dulen, D., Beck, C. and Auble, B. (2013). Surface ozone at the Devils Postpile National Monument receptor site during low and high wildland fire years. Atmos. Environ. 65: 129141.

Bytnerowicz, A., Hsu, Y.M., Percy, K., Legge, A., Fenn, M.E., Schilling, S., Frączek, W. and Alexander, D. (2016). Ground-level air pollution changes during a boreal wildland mega-fire. Sci. Total Environ. 572: 755769.

Bytnerowicz, A., Fenn, M.E., Cisneros, R., Schweizer, D., Burley, J. and Schilling, S.L. (2019). Nitrogenous air pollutants and ozone exposure in the central Sierra Nevada and White Mountains of California - Distribution and evaluation of ecological risks. Sci. Total Environ. 654: 604-615.

Cascio, W.E. (2018). Wildland fire smoke and human health. Sci. Total Environ. 624: 586-595.

Cereceda-Balic, F., Toledo, M., Vidal, V., Guerrero, F., Diaz-Robles, L.A., Petit-Breuilh, X. and Lapuerta, M. (2017). Emission factors for $\mathrm{PM}_{2.5}, \mathrm{CO}, \mathrm{CO}_{2}, \mathrm{NO}_{\mathrm{x}}, \mathrm{SO}_{2}$ and particle size distributions from the combustion of wood species using a new controlled combustion chamber 3CE. Sci. Total Environ. 584-585: 901-910.

Coen, J. (2018). Some requirements for simulating wildland fire behavior using insight from coupled weather-Wildland fire models. Fire 1: 6.

Collins, B.M., Miller, J.D., Knapp, E.E. and Sapsis, D.B. (2019). A quantitative comparison of forest fires in central and northern California under early (1911-1924) and contemporary (2002-2015) fire suppression. Int. J. Wildland Fire 28: 138-148.

Diapouli, E., Manousakas, M., Vratolis, S., Vasilatou, V., Maggos, T., Saraga, D., Grigoratos, T., Argyropoulos, G., Voutsa, D., Samara, C. and Eleftheriadis, K. (2017). Evolution of air pollution source contributions over one decade, derived by $\mathrm{PM}_{10}$ and $\mathrm{PM}_{2.5}$ source apportionment in two metropolitan urban areas in Greece. Atmos. Environ. 164: 416-430.

Evtyugina, M., Calvo, A.I., Nunes, T., Alves, C., Fernandes, A.P., Tarelho, L., Vicente, A. and Pio, C. (2013). VOC emissions of smouldering combustion from Mediterranean wildfires in central Portugal. Atmos. Environ. 64: 339348.

Fowler, C. (2003). Human health impacts of forest fires in the southern United States: A literature review. J. Ecol. Anthropol. 7: 39-63.

Hosseini, S., Urbanski, S.P., Dixit, P., Qi, L., Burling, I.R., Yokelson, R.J., Johnson, T.J., Shrivastava, M., Jung, H.S., Weise, D.R., Miller, J.W. and Cocker, D.R. (2013). Laboratory characterization of PM emissions from combustion of wildland biomass fuels. J. Geophys.
Res. Atmos. 118: 9914-9929.

Huang, Y., Shen, H., Chen, H., Wang, R., Zhang, Y., Su, S., Chen, Y., Lin, N., Zhuo, S., Zhong, Q., Wang, X., Liu, J., Li, B., Liu, W. and Tao, S. (2014). Quantification of global primary emissions of $\mathrm{PM}_{2.5}$, $\mathrm{PM}_{10}$, and TSP from combustion and industrial process sources. Environ. Sci. Technol. 48: 13834-13843.

Hueglin, C., Gehrig, R., Baltensperger, U., Gysel, M., Monn, C. and Vonmont, H. (2005). Chemical characterisation of $\mathrm{PM}_{2.5}, \mathrm{PM}_{10}$ and coarse particles at urban, near-city and rural sites in Switzerland. Atmos. Environ. 39: 637-651.

Kozákovác, J., Leoni, C., Klán, M., Hovorka, J., Racek, M., Koštejn, M., Ondráček, J., Moravec, P. and Schwarz, J. (2018). Chemical characterization of $\mathrm{PM}_{1-2.5}$ and its associations with $\mathrm{PM}_{1}, \mathrm{PM}_{2.5-10}$ and Meteorology in urban and suburban environments. Aerosol Air Qual. Res. 18: 1684-1697.

Landis, M.S., Edgerton, E.S., White, E.M., Wentworth, G.R., Sullivan, A.P. and Dillner, A.M. (2018). The impact of the 2016 Fort McMurray Horse River Wildfire on ambient air pollution levels in the Athabasca Oil Sands Region, Alberta, Canada. Sci. Total Environ. 618: 16651676.

Met One Instruments (2008). E-Bam Particulate Monitor Operation Manual E-BAM-9800 Rev L. Met One Instruments, Inc., Grants Pass, OR.

Miller, J.D. and Safford, H.D. (2017). Corroborating evidence of a pre-Euro-American low- to moderateseverity fire regime in yellow pine-mixed conifer forests of the Sierra Nevada, California, USA. Fire Ecol. 13: 58-90.

Miller, J.D., Safford, H.D., Crimmins, M. and Thode, A.E. (2009). Quantitative evidence for increasing forest fire severity in the Sierra Nevada and southern Cascade Mountains, California and Nevada, USA. Ecosystems 12: $16-32$.

Navarro, K., Schweizer, D., Balmes, J. and Cisneros, R. (2018). A review of community smoke exposure from wildfire compared to prescribed fire in the United States. Atmosphere 9: 185.

R Core Team (2018). R: A language and environment for statistical computing.

Radke, L.F., Hegg, A.S., Hobbs, P.V. and Penner, J.E. (1995). Effects of aging on the smoke from a large forest fire. Atmos. Res. 38: 315-332.

Reid, C.E., Brauer, M., Johnston, F.H., Jerrett, M., Balmes, J.R. and Elliott, C.T. (2016). Critical review of health impacts of wildfire smoke Exposure. Environ. Health Perspect. 124: 1334-1343.

Reisen, F., Meyer, C.P., Weston, C.J. and Volkova, L. (2018). Ground-based field measurements of $\mathrm{PM}_{2.5}$ emission factors from flaming and smoldering combustion in eucalypt forests. J. Geophys. Res. Atmos. 123: 83018314.

Schweizer, D., Cisneros, R. and Shaw, G. (2016). A comparative analysis of temporary and permanent beta attenuation monitors: The importance of understanding data and equipment limitations when creating $\mathrm{PM}_{2.5}$ air 
quality health advisories. Atmos. Pollut. Res. 7: 865875.

Sharma, R. and Balasubramanian, R. (2018). Sizefractionated particulate matter in indoor and outdoor environments during the 2015 haze in Singapore: Potential human health risk assessment. Aerosol Air Qual. Res. 18: 904-917.

Statheropoulos, M. and Karma, S. (2007). Complexity and origin of the smoke components as measured near the flame-front of a real forest fire incident: A case study. $J$. Anal. Appl. Pyrolysis 78: 430-437.

Stephens, S.L., Martin, R.E. and Clinton, N.E. (2007). Prehistoric fire area and emissions from California's forests, woodlands, shrublands, and grasslands. For. Ecol. Manage. 251: 205-216.

Thuy, N.T.T., Dung, N.T., Sekiguchi, K., Thuy, L.B., Hien, N.T.T. and Yamaguchi, R. (2018). Mass concentrations and carbonaceous compositions of $\mathrm{PM}_{0.1}, \mathrm{PM}_{2.5}$, and $\mathrm{PM}_{10}$ at urban locations of Hanoi, Vietnam. Aerosol Air
Qual. Res. 18: 1591-1605.

Vicente, A., Alves, C., Calvo, A.I., Fernandes, A.P., Nunes, T., Monteiro, C., Almeida, S.M. and Pio, C. (2013). Emission factors and detailed chemical composition of smoke particles from the 2010 wildfire season. Atmos. Environ. 71: 295-303.

Wegesser, T.C., Pinkerton, K.E. and Last, J.A. (2009). California wildfires of 2008: Coarse and fine particulate matter toxicity. Environ. Health Perspect. 117: 893897.

Wentworth, G.R., Aklilu, Y., Landis, M.S. and Hsu, Y.M. (2018). Impacts of a large boreal wildfire on ground level atmospheric concentrations of PAHs, VOCs and ozone. Atmos. Environ. 178: 19-30.

Received for review, April 22, 2019

Revised, June 10, 2019

Accepted, June 14, 2019 